\title{
Toll/Interleukin-1 receptor member ST2 exhibits higher soluble levels in type 2 diabetes, especially when accompanied with left ventricular diastolic dysfunction
}

Evangelos Fousteris ${ }^{1 *}$, Andreas Melidonis ${ }^{1}$, George Panoutsopoulos ${ }^{2}$, Konstantinos Tzirogiannis $^{1}$, Stefanos Foussas ${ }^{3}$, Anastasios Theodosis-Georgilas ${ }^{3}$, Stavros Tzerefos ${ }^{3}$, Spiridon Matsagos ${ }^{4}$, Eleni Boutati ${ }^{5}$, Theofanis Economopoulos ${ }^{5}$, George Dimitriadis ${ }^{5}$ and Sotirios Raptis ${ }^{5,6}$

\begin{abstract}
Background: Soluble ST2, a member of the of the Toll/IL-1 superfamily, is a novel biomarker with exceptional predictive value in heart failure and myocardial infarction- related mortality as well as in acute dyspneic states. Soluble ST2 is considered a decoy receptor of IL 33 that blocks the protective effects of the cytokine in atherosclerosis and cardiac remodeling. In the present study we investigated the differences in the levels of soluble ST2, BNP and hs-CRP between healthy controls and patients with type 2 diabetes with and without left ventricular diastolic dysfunction. A secondary aim was to investigate correlations between sST2 and other biomarkers of type 2 diabetes, such as HbA1c.
\end{abstract}

Methods: 158 volunteers were recruited and underwent a complete Doppler-echocardiographic evaluation of both systolic \& diastolic cardiac function. All subjects with ejection fraction $<50 \%$ were excluded. The study population was divided in 4 groups as follows: A: 42 healthy controls, B: 18 subjects without diabetes with LVDD, C: 48 patients with type 2 diabetes without LVDD \& D: 50 patients with type 2 diabetes \& LVDD. ELISA technique was performed to measure sST2 levels. Statistical analysis was performed with Kruskal-Wallis \& Mann-Whitney test (continuous variables), chi squared \& Fischer exact test (discrete variables), Spearman coefficient (univariate analysis) and step-wise backward method (multivariate analysis).

Results: Patients with type 2 diabetes with $(p<0.001)$ or without LVDD $(p=0.007)$ had higher serum ST2 levels compared to healthy controls, state found also for hs-CRP levels but not for the corresponding BNP levels ( $p=$ $0.213 \& p=0.207$ respectively). Patients with type 2 diabetes \& LVDD had higher serum ST2 in relation to diabetic patients without LVDD ( $p=0.001$ ). In multivariate analysis HbA1c positively and independently correlated with sST2 levels in both groups of patients with type 2 diabetes.

Conclusions: Patients with type 2 diabetes exhibit higher sST2 levels compared to healthy controls. The presence of LVDD in patients with type 2 diabetes is associated with even higher sST2 levels. A significant correlation between glycemic control and SST2 levels was also revealed.

Keywords: Soluble ST2, BNP, hs-CRP, type 2 diabetes, diastolic dysfunction

\footnotetext{
* Correspondence: fousteris@mycosmos.gr

'Diabetes Center, "Tzanio" General Hospital of Piraeus, Greece

Full list of author information is available at the end of the article
} 


\section{Background}

Soluble ST2, a member of the of the Toll/IL-1 superfamily, is a novel biomarker of myocardial mechanical stress with exceptional predictive value in heart failure and myocardial infarction- related mortality [1-7] as well as in acute dyspneic states [8-11]. Soluble ST2 is considered a decoy receptor of IL 33 (a member of IL-1 receptor family of cytokines) that blocks the protective effects of the cytokine in atherosclerosis, obesity and cardiac remodeling $[3,4]$.

IL-33 is a cytokine with dual function, acting both as a traditional cytokine implicated in numerous inflammatory disorders and as a transcriptional factor [12].IL-33 is expressed in various tissues and in the heart and vascular tree and is considered to play a significant role in various cardiovascular disorders [13]. In relation to atherosclerosis, IL-33 is speculated to exert an anti-atherosclerotic effect by inducing a Th1-to-Th2 immune response [13], arresting foam cell formation [14], stimulating IL-5 production and oxidized low-density lipoprotein antibodies [15]. Downstream activation of NF-kB and the MAPK kinases by IL-33 also competitively inhibits excessive activation of these pathways by more potent activators, such as angiotensin II and phenylephrine, that are connected to increased ROS production [16]. The role of IL33/ST2 signaling pathway in the heart remains hugely unveiled today and according to current knowledge it is considered a paracrine cardioprotective pathway between cardiomyocytes and cardiac fibroblasts [16]. In an animal model of pressure overload, IL 33 treatment reduced cardiac hypertrophy and fibrosis and improved survival [16]. The same cytokine also exerts antiapoptotic effects through suppression of caspace- 3 and increased expression of inhibitors of apoptosis [17].

In the immune system IL-33, through its receptor T1/ ST2 (transmembrane form of ST2), exerts a pivotal role in Th2 responses, as well as in mast cell and eosinophil activation through activation of NF-kB and MAP Kinases [18-20]. Soluble ST2 levels have been found elevated in an array of human diseases including asthma, allergic airway inflammation, systemic lupus erythematosus, rheumatoid arthritis, idiopathic pulmonary fibrosis and sepsis. Several studies have also shown a beneficial effect after soluble ST2 administration in animal models of inflammatory disease [18]. These results have been attributed to the blockade of IL 33 actions with downstream suppression of NF-kB activation [18].

In relation to diabetes, IL33 exerted protective effects in an animal model of obese diabetic mice (ob/ob) reducing adiposity, fasting plasma glucose and improving glucose tolerance and insulin resistance [21].

In the present study we investigated the differences in the levels of soluble ST2, B-type natriuretic peptide
(BNP) and high sensitivity $\mathrm{C}$ - reactive protein (hs-CRP) between healthy controls and patients with type 2 diabetes with and without left ventricular diastolic dysfunction (LVDD). A secondary aim was to investigate correlations between sST2 and other biomarkers of type 2 diabetes, such as glycosylated hemoglobin (HbA1c).

\section{Methods}

This is a prospectively conducted study that took place in an urban general hospital in Piraeus, Greece from July 2009 to July 2010 . The study protocol is in compliance with the Helsinki Declaration and was approved by the ethical committee of the hospital (5/10-04-2009). The diabetic population of our sample was recruited from the Diabetes Center of our hospital. People with type 2 diabetes were informed about the study protocol and were voluntarily recruited after consent. People without diabetes (controls) were chosen from the echocardiography unit of the cardiology department of the same hospital among patients without history of cardiac diseases, in whom the indication for echocardiography was "atypical chest pain". They were also voluntarily recruited after informed consent.

Subjects with impaired systolic function (ejection fraction of left ventricle $<50 \%$ ) or history of coronary artery disease were excluded. Other exclusion criteria included history of: arrhythmias, cardiac valvular disorders, malignancies, autoimmune diseases and other inflammatory states, Cushing's syndrome and use of corticosteroids or thiazolinediones.

Subjects underwent a complete Doppler-echocardiographic evaluation. Echocardiography (and especially Tissue Doppler Imaging) was used to diagnose subjects with left ventricular systolic and/or diastolic dysfunction (according to the revised guidelines of A.C.C./A.H.A. 2009). Studies were performed on a Vivid 7 echocardiography machine (Vingmed, Norway). All measurements were made by a single experienced echocardiographer blinded to the diabetic status of the patients according to the ASE recommendations for chamber quantification 20051. The LV ejection fraction was estimated using the Simpson biplane method. From the mitral inflow profile, the E- and A-wave peak velocities and DT were measured. The E' velocity from the septal and lateral mitral valve annulus and the mean value were determined, and the respective E/E' ratios were derived. An E/E'septal ratio $>15$ was considered indicative of elevated LV filling pressure. Diastolic function was categorized using mitral inflow and Doppler Tissue Imaging parameters. Grade 3 diastolic dysfunction (restrictive) was defined as an E/ A ratio $>2$ and/or DT $<150$ milliseconds; and Grade 1 dysfunction (impaired relaxation), as an E/A ratio $<1$ and/or a DT $>220$ milliseconds. Grade 2 dysfunction 
(pseudonormal) was diagnosed where the DT was between 150 and 220 milliseconds and the E/A ratio was between 1 and 2, but either the E/e'septal was $>10$ and/or the E/A ratio fell to $<1$ with Valsalva. Remaining subjects were categorized as having normal diastolic function.

Finally, 158 Caucasian volunteers [60 subjects without diabetes and 98 patients with type 2 diabetes, mean age \pm standard deviation (SD) $56.24 \pm 9.78$ years] were included (convenient sample). Echocardiograms allowed the division of the study population in 4 groups: Group A: 42 healthy controls, Group B: 18 subjects without diabetes with LVDD, Group C: 48 patients with type 2 diabetes without LVDD, Group D: 50 patients with type 2 diabetes \& LVDD.

Height and weight were measured in all subjects to calculate the Body Mass Index (BMI in $\mathrm{Kg} / \mathrm{m}^{2}$ ). Fasting blood samples were analyzed for: fasting plasma glucose (FPG), urea \& creatinine [in order to estimate glomerular filtration rate (eGFR) according to the Cockroft-Gault formula], total Cholesterol, high density lipoproteins (HDL), low density lipoproteins (LDL), triglycerides, BNP, hs$\mathrm{CRP}, \mathrm{HbA} 1 \mathrm{c}$ and fibrinogen, using the standard procedures of the biochemistry laboratory of our hospital.

The serum of the participants was kept at $-70^{\circ} \mathrm{C}$ and was processed within 6 months after sampling using the Presage ${ }^{\circledR}$ ST2 ELISA kit (Critical Diagnostics, U.S.A.) in order to measure the Soluble ST2 levels.

Statistical analysis was performed with Kruskal-Wallis test \& Mann-Whitney test (for continuous variables) and $\mathrm{x}^{2}$ test or Fischer exact test (for discrete variables). Spearman coefficient was used for the univariate analysis, whereas the step-wise backward method for the multivariate analysis. The main study hypothesis was that sST2 levels differed significantly among the 4 study groups (H1).

\section{Results}

Age, sex and duration of diabetes did not differ significantly among the study groups. Statistical variability was only observed for mean BMI among the study groups (table 1) with group A to present lower mean BMI values compared with groups $B(p=0,001)$ and $D(p=$ $0,002)$. Univariate analysis, though, in groups $C$ and $D$ (patients with type 2 diabetes) did not prove that BMI impact on the circulating sST2 levels. The subjects of groups B \& D (LVDD present) had more frequently history of hypertension (for B: $66.7 \%$ \& D: $76 \%$ ) in relation to the remaining 2 groups (LVDD absent). Additionally all members of groups B and D exhibited the impaired relaxation pattern (grade 1 LVDD) in the echocardiograms.

Significant variability among the 4 study groups was observed for the mean values of sST2 $(\mathrm{p}<0.001)$, hs-
Table 1 Demographic characteristics of the study population

\begin{tabular}{|c|c|c|c|c|}
\hline VARIABLE & GROUP & Mean & S.D. & p-value \\
\hline \multirow{5}{*}{$\begin{array}{c}\mathrm{AGE} \\
\text { (years) }\end{array}$} & A & 55,10 & 10,50 & 0,107 \\
\hline & B & 60,33 & 9,65 & \\
\hline & C & 54,87 & 9,94 & \\
\hline & D & 56,98 & 8,80 & \\
\hline & TOTAL & 56,24 & 9,78 & \\
\hline \multirow{5}{*}{$\begin{array}{c}\text { SEX } \\
\text { (\% males) }\end{array}$} & A & 61,90 & NA & 0,081 \\
\hline & B & 77,80 & NA & \\
\hline & C & 45,80 & NA & \\
\hline & $\mathrm{D}$ & 50,00 & NA & \\
\hline & TOTAL & 58,90 & NA & \\
\hline \multirow[t]{4}{*}{ DURATION OF DIABETES (years) } & A & NA & NA & 0,136 \\
\hline & B & NA & NA & \\
\hline & C & 2,81 & 2,50 & \\
\hline & D & 4,97 & 6,03 & \\
\hline \multirow{4}{*}{$\begin{array}{c}\mathrm{BMI} \\
\left(\mathrm{Kg} / \mathrm{m}^{2}\right)\end{array}$} & A & 27,83 & 4,62 & 0,005 \\
\hline & B & 32,63 & 6,45 & \\
\hline & C & 29,41 & 5,13 & \\
\hline & $D$ & 31,69 & 7,77 & \\
\hline
\end{tabular}

We used the Kruskal-Wallis test to analyze the variability of age, duration of diabetes \& BMI and the chi squared test to analyze the sex variability between the 4 study groups. P-value found significant only for BMI, where the relative value of group $A$ was significantly lesser than the correspondent of group $B(p=0,001)$ and group $D(p=0,002)$. All the other possible comparisons of BMI were found to be statistically insignificant. (NA $=$ Not applicable)

CRP $(\mathrm{p}=0.039)$, FPG $(\mathrm{p}<0.001)$, total Cholesterol $(\mathrm{p}<$ $0.001)$, HDL $(\mathrm{p}<0.001)$, LDL $(\mathrm{p}<0.001)$, triglycerides $(\mathrm{p}=0.002)$ and HbA1c $(\mathrm{p}<0.001)$. Mean HbA1c of Group A was 6,08\%, Group B 6,46\%, Group C 8,67\% and Group D 7,92\%. Mean HbA1c of non-diabetic population was significantly lower than the correspondent of patients with type 2 diabetes, as expected. Mean HbA1c of Group C did not differ statistically compared to the correspondent of Group D ( $p=0,157)$. No variability was found for the mean values of BNP ( $\mathrm{p}=$ $0.301)$, fibrinogen $(p=0.302)$ and eGFR $(p=0.393)$ (table 2).

Soluble ST2 (mean \pm SD) was $9.16 \pm 4.56 \mathrm{ng} / \mathrm{ml}$ for healthy controls (Group A), $9.93 \pm 3.57 \mathrm{ng} / \mathrm{ml}$ for subjects without diabetes with LVDD (Group B), $11.31 \pm$ $3.05 \mathrm{ng} / \mathrm{ml}$ for patients with type 2 diabetes without LVDD (Group C) and $14.97 \pm 5.23 \mathrm{ng} / \mathrm{ml}$ for patients with type 2 diabetes \& LVDD (Group D) (Figure 1). Soluble ST2 levels did not differ significantly between groups A and B (subjects without diabetes) $(\mathrm{p}=0.514)$. Statistically significant difference was observed between healthy controls (group A) and patients with type 2 
Table 2 Results of the study's parameters

\begin{tabular}{|c|c|c|c|c|}
\hline VARIABLE & GROUP & Mean & S.D. & $p$-value \\
\hline \multirow[t]{4}{*}{ Soluble ST2 (ng/ml) } & $A$ & 9,16 & 4,56 & $<0,001$ \\
\hline & $B$ & 9,93 & 3,57 & \\
\hline & C & 11,31 & 3,05 & \\
\hline & $\mathrm{D}$ & 14,97 & 5,23 & \\
\hline \multirow[t]{4}{*}{ BNP (pg/ml) } & $A$ & 28,78 & 13,73 & 0,301 \\
\hline & $B$ & 33,37 & 19,88 & \\
\hline & $C$ & 40,06 & 31,39 & \\
\hline & $\mathrm{D}$ & 29,63 & 22,55 & \\
\hline \multirow{4}{*}{$\begin{array}{l}\text { hs-CRP } \\
\text { (mg/lt) }\end{array}$} & $A$ & 3,04 & 4,45 & 0,039 \\
\hline & B & 3,34 & 4,87 & \\
\hline & C & 5,61 & 6,21 & \\
\hline & $D$ & 6,35 & 5,79 & \\
\hline \multirow{4}{*}{$\begin{array}{l}\text { Fibrinogen } \\
\text { (gr/lt) }\end{array}$} & $A$ & 4,00 & 0,81 & 0,302 \\
\hline & B & 3,84 & 0,60 & \\
\hline & $C$ & 4,35 & 1,55 & \\
\hline & $\mathrm{D}$ & 3,82 & 1,21 & \\
\hline \multirow{4}{*}{$\begin{array}{l}\text { Fasting Plasma Glucose } \\
\text { (mg/dl) }\end{array}$} & $A$ & 94,71 & 10,24 & $<0,001$ \\
\hline & B & 100,00 & 11,48 & \\
\hline & C & 137,75 & 37,59 & \\
\hline & D & 136,54 & 30,05 & \\
\hline \multirow{4}{*}{$\begin{array}{c}\text { eGFR } \\
\text { (mlt/min) }\end{array}$} & $A$ & 106,70 & 27,05 & 0,393 \\
\hline & $B$ & 107,44 & 27,90 & \\
\hline & $C$ & 120,58 & 44,68 & \\
\hline & $D$ & 124,50 & 43,61 & \\
\hline \multirow[t]{4}{*}{ Total Cholesterol (mg/dl) } & A & 211,57 & 34,83 & $<0,001$ \\
\hline & B & 222,00 & 44,74 & \\
\hline & C & 208,88 & 44,95 & \\
\hline & $\mathrm{D}$ & 173,64 & 39,03 & \\
\hline \multirow{4}{*}{$\begin{array}{c}\mathrm{HDL} \\
(\mathrm{mg} / \mathrm{dl})\end{array}$} & A & 51,24 & 11,67 & $<0,001$ \\
\hline & $B$ & 49,33 & 14,42 & \\
\hline & $C$ & 47,25 & 15,97 & \\
\hline & $\mathrm{D}$ & 39,60 & 9,96 & \\
\hline \multirow{4}{*}{$\begin{array}{c}\mathrm{LDL} \\
(\mathrm{mg} / \mathrm{dl})\end{array}$} & $A$ & 136,83 & 30,12 & $<0,001$ \\
\hline & $B$ & 143,84 & 36,66 & \\
\hline & $C$ & 137,13 & 37,22 & \\
\hline & D & 101,22 & 36,66 & \\
\hline \multirow[t]{4}{*}{ Triglycerides (mg/dl) } & A & 116,52 & 43,80 & 0,002 \\
\hline & $B$ & 148,56 & 47,83 & \\
\hline & C & 124,25 & 52,77 & \\
\hline & $\mathrm{D}$ & 159,30 & 73,90 & \\
\hline \multirow{2}{*}{$\begin{array}{l}\text { HbA1c } \\
(\%)\end{array}$} & $A$ & 6,08 & 0,36 & $<0,001$ \\
\hline & $B$ & 6,46 & 0,38 & \\
\hline
\end{tabular}

Table 2 Results of the study?'?s parameters (Continued)

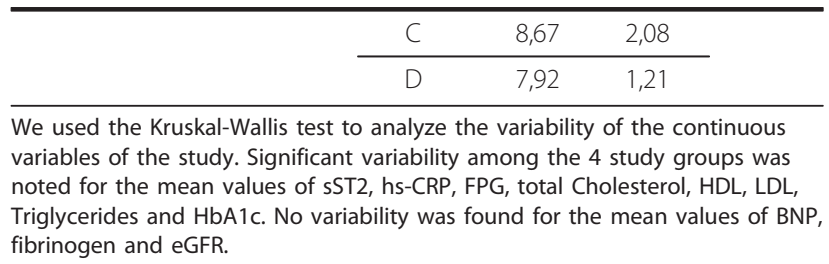

diabetes without LVDD (group C) $(\mathrm{p}=0.007)$. Moreover, patients with type 2 diabetes with LVDD (group D) had the highest serum levels of sST2 among the 4 study groups (table 3 ).

The respective mean values of BNP for the 4 study groups were: A: $28.78 \pm 13.73 \mathrm{pg} / \mathrm{ml}, \mathrm{B}: 33.37 \pm 19.88$ $\mathrm{pg} / \mathrm{ml}, \mathrm{C}: 40.06 \pm 31.39 \mathrm{pg} / \mathrm{ml}$ and D: $29.63 \pm 22.55 \mathrm{pg} /$ $\mathrm{ml}$ without statistically significant differences between the 4 study groups (table 3 ).

The mean hs-CRP of group A was 3,04 $\pm 4,44 \mathrm{mg} / \mathrm{l}$, group B 3,34 $\pm 4,87 \mathrm{mg} / \mathrm{l}$, group C 5,61 $\pm 6,21 \mathrm{mg} / \mathrm{l}$ and group D 6,35 $\pm 7,79 \mathrm{mg} / \mathrm{l}$. No difference was found for the mean values of hs-CRP between groups $\mathrm{A} v s \mathrm{~B}$ and $C$ vs D. All subjects with type 2 diabetes (Groups $C$ and D) presented higher hs-CRP levels compared to the non-diabetic population (Groups A and B) of the study (table 3).

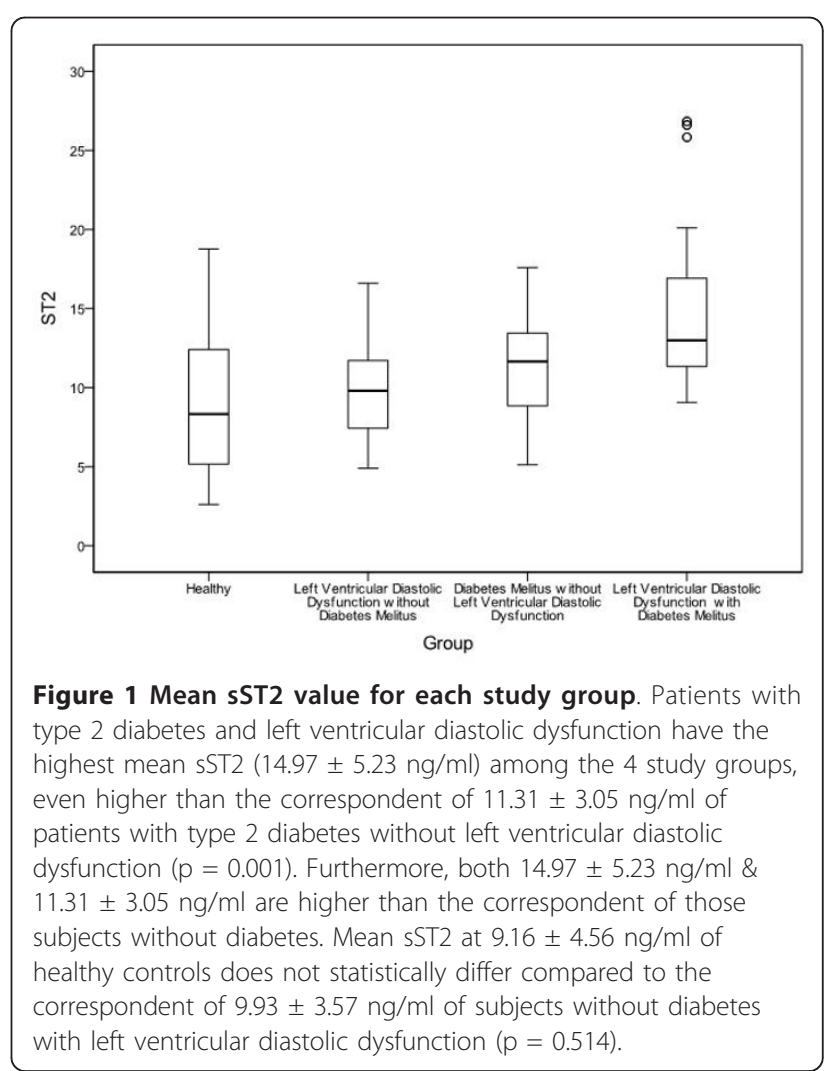


Table 3 Comparison of mean value of sST2, BNP and hsCRP between the 4 study groups

\begin{tabular}{cccc}
\hline Comparison & \multicolumn{3}{c}{ p-value } \\
\cline { 2 - 4 } & $\mathbf{s S T 2}$ & BNP & hs-CRP \\
\hline A vs B & 0,514 & 0,628 & 0,872 \\
\hline A vs C & $\mathbf{0 , 0 0 7}$ & 0,213 & $\mathbf{0 , 0 0 4}$ \\
\hline A vs D & $<\mathbf{0 , 0 0 1}$ & 0,207 & $\mathbf{0 , 0 1 7}$ \\
\hline B vs C & 0,121 & 0,863 & $\mathbf{0 , 0 4 1}$ \\
\hline B vs D & $<\mathbf{0 , 0 0 1}$ & 0,504 & $\mathbf{0 , 0 4 8}$ \\
\hline C vs D & $\mathbf{0 , 0 0 1}$ & 0,091 & 0,659 \\
\hline Overall & $<\mathbf{0 , 0 0 1}$ & 0,301 & $\mathbf{0 , 0 3 9}$ \\
\hline
\end{tabular}

Soluble ST2 was significantly different between group A (healthy controls) and patients with type 2 diabetes without (group C) LVDD $(p=0.007)$. Moreover, patients with type 2 diabetes with LVDD (group D) had the highest mean serum level of SST2 compared to the correspondent of the rest 3 subject groups: group A $(p<0.001)$, group B $(p<0.001)$ and group $C(p=0.001)$. The respective mean values of BNP for the 4 study groups could not achieve statistical difference. All subjects with type 2 diabetes presented higher hsCRP levels compared to the non-diabetic population of the study.

When focusing in Group $\mathbf{C}$ (patients with type 2 diabetes without LVDD), univariate analysis showed that sST2 levels correlated positively with hs-CRP levels $(\mathrm{p}=$ $0.04)$, fibrinogen $(p=0.027)$, fasting plasma glucose (FPG) $(\mathrm{p}<0.01)$, HbA1c $(\mathrm{p}<0.01)$ and negatively correlated with the HDL $(\mathrm{p}<0.01)$, sex (females) $(\mathrm{p}<0.01)$, history of hypertension $(\mathrm{p}=0.045)$ and chronic obstructive pulmonary disease $(p=0.01)$. No correlation was confirmed between sST2 and age $(\mathrm{p}=0.513), \mathrm{BMI}(\mathrm{p}=$ $0.603)$, duration of diabetes $(\mathrm{p}=0.297)$, BNP $(\mathrm{p}=$ $0.512)$, eGFR $(\mathrm{p}=0.070)$, total Cholesterol $(\mathrm{p}=0.580)$, LDL $(\mathrm{p}=0.613)$, Triglycerides $(\mathrm{p}=0.091)$. Multivariate analysis manifested HDL, HbA1c, sex, history of hypertension and COPD as the most powerful and independent parameters of sST2, that predict and/or interpret the $81 \%$ of sST2 variability in this group.

Similar statistical analysis in Group D (patients with type 2 diabetes \& LVDD) revealed that sST2 levels positively correlated with $\mathrm{HbA1c}(\mathrm{p}<0,01)$ and hs-CRP levels $(\mathrm{p}=0,042)$ and negatively only with HDL $(\mathrm{p}=$ 0.041 ). Multivariate analysis, though, manifested solely $\mathrm{HbA1c}$ as the unique independent parameter that affects the serum ST2 value in group D.

\section{Discussion}

The results of the present study indicate that type 2 diabetes (with or without LVDD) is connected with higher sST2 levels that positively correlate with hs-CRP levels and the extend of glycemic control (HbA1c).

Today it is known that type 2 diabetes is associated with low-grade chronic inflammation that in part emanates from activation of the innate immune system [22] that gives rise to the acute phase response in which CRP plays a fundamental role [22] and several studies have documented the connection between high CRP levels and type 2 diabetes in the presence or absence of obesity $[23,24]$. Soluble ST2 levels have also been found elevated in numerous inflammatory disorders which are thought to exert a protective effect and from this point of view the correlation of sST2 levels with CRP levels in diabetics in our study most possibly reflects the inflammatory component of diabetes. In this context, increased sST2 levels represent a counterregulatory mechanism to chronic inflammation. In accordance with the above speculation is also the observed correlation between sST2 levels and extent of glycemic control as indicated by HbA1c levels.

Patients with type 2 diabetes and grade 1 LVDD, an early finding of diabetic cardiomyopathy [25,26], exhibited the highest sST2 levels in our study. The lack of diabetic patients with higher grades of LVDD did not allow further remarks on the quantitative relationship between sST2 levels and the grade of LVDD in the present study and further research is needed at this point. The increased sST2 levels in patients with diabetes and LVDD cannot be attributed to chronic inflammation or increased glycemic burden since no statistically significant differences for hs- CRP and HbA1c have been observed between the two groups of diabetic patients.

Several studies have established the prognostic role of sST2 levels in myocardial infarction, heart failure, right ventricle function and dyspneic states, while there are no available data about IL-33 levels in cardiovascular disorders [13]. Today studies from animal models suggest that sST2 is more than just a marker in cardiovascular disease and implicate IL33/ST2 signaling as an important protective pathway in which the role of sST2 remains obscure [13]. In states of oxidative stress as in diabetes increased expression of endothelin 1 has been found paradoxically to restore diastolic dysfunction [27] and endothelin 1 is a known inducer of sST2 expression and inhibitor of IL-33 signaling through p38 MAPK [28]. From this point of view, increased levels of sST2 in patients with diabetes and LVDD might be an epiphenomenon of other counteregulatory mechanisms such as endothelin 1 or to signify patients with failure of IL-33-induced cardioprotection, through SST2 acting as a decoy receptor.

TLRs are broadly distributed on immune cells and represent primordial recognition receptors mediating activation of the innate immune system [29]. Several recent studies have revealed attenuation of TLR4 and TLR2 signaling by the ST2 pathway with subsequent diminished production of proinflammatory cytokines [30-32]. In relation to infectious disease administration of sST2 protects mice against endotoxin-induced shock [31] and the IL-33/ST2 signaling pathway also prevents an inappropriate parasite specific Th1 polarized response by induction of IL-4, IL-9 and IL-13 [33] and the above findings suggest a major regulatory role of the 
ST2 pathway in controlling aberrant inflammatory response.

IL-33/ST2 signaling is also implicated in autoimmune disease and in an experimental animal model of diabetes I induction by multiple doses of streptozotocin this pathway seems to exert a protective effect possible through balancing Th1/Th2 response [34]. Additionally endothelial cells from type I diabetic mice have been found to exhibit enhanced inflammatory responses after stimulation of TLR2 and TLR 4 through augmented NF-kB activation [35].

The role of IL-33/ST2 pathway in type I and II diabetes remains vastly unknown today. In type II diabetes the molecular mechanisms that induce inflammatory mediators are still being elucidated and TLRs are considered primary effector molecules in this process that are also activated by nutritional factors as FFA. Ligand binding by TLRs triggers the inflammatory cascade and insulin homeostasis dysregulation [22]. Apart from the innate immune system the adaptive immunity seems also to be implicated in the chronic inflammation of type II diabetes and CD4-positive $\mathrm{T}$ lymphocytes are the first cells to infiltrate fat tissue [36]. From this point of view IL-33/ ST2 pathway might prove to be a crucial pathway in balancing the intensity of inflammation in diabetes.

Subjects without diabetes \pm LVDD exhibited similar mean serum ST2 values and this underlines the fact that sST2 does not represent a mere index of diastolic dysfunction but rather an indicator of a deranged metabolic environment of chronic inflammation and oxidative stress in which cardiovascular damage develops.

In conclusion, this is the first study to document elevated sST2 levels in type 2 diabetes. Chronic inflammation most possibly establishes the basis of increased soluble ST2 levels and diastolic dysfunction seems also to be connected with further increase of this biomarker with still obscure mechanisms.

\section{Conclusion}

This is the first study to document increased levels of soluble ST2 in patients with type 2 diabetes in general with higher elevations in the presence of LVDD. Further research with bigger populations needs to be done in order to abut on more general conclusions.

\begin{abstract}
Abbreviations
LVDD: Left ventricular diastolic dysfunction; eGFR: Estimated glomerular filtration rate; hs-CRP: High sensitivity C-reactive protein; BNP: B-type natriuretic peptide; HbA1c: Glycosylated hemoglobin; FPG: Fasting plasma glucose; HDL: High density lipoproteins; LDL: Low density lipoproteins; SD: Standard Deviation.
\end{abstract}

\section{Acknowledgements}

This study was funded by Hellenic National Diabetes Center. Authors would like to acknowledge the substantial contributions of Dr. Stylianos Hantanis regarding the performance of the echocardiographs of this study, as well as the contributions of Dr. Panagiota Spyropoulou, who has been a great support for the conduct of the ELISA tests.

\section{Author details}

'Diabetes Center, "Tzanio" General Hospital of Piraeus, Greece. ²Department of Nursing, Faculty of Human Movement and Quality of Life Sciences, University of Peloponnese, Greece. ${ }^{3}$ Cardiology Department, Tzanio General Hospital of Piraeus, Greece. ${ }^{4}$ Blood Bank Service, Tzanio General Hospital of Piraeus, Greece. ${ }^{5} 2^{\text {nd }}$ Department of Internal Medicine, Research Institute \& Diabetes Center, "Attikon" University General Hospital, Greece. ${ }^{6}$ Hellenic National Diabetes Center, Athens, Greece.

\section{Authors' contributions}

$E F, A M, K T, E B, T E, G D$ and $S R$ have made substantial contributions to conception and design of the study, acquisition of data, analysis and interpretation of data. GP performed the statistical analysis of the study. SF ATG and ST have made substantial contributions to the performance of all the echocardiographies. SM participated in the measure of soluble ST2. All authors read and approved the final manuscript.

\section{Competing interests}

The authors declare that they have no competing interests.

Received: 8 November 2011 Accepted: 21 November 2011

Published: 21 November 2011

\section{References}

1. Weinberg EO, Shimpo M, Hurwitz S, Tominaga S, Rouleau JL, Lee RT: Identification of serum soluble ST2 receptor as a novel heart failure biomarker. Circulation 2003, 107(5):721-6.

2. Weinberg EO, Shimpo M, De Keulenaer GW, MacGillivray C, Tominaga S, Solomon SD, Rouleau JL, Lee RT: Expression and regulation of ST2, an interleukin-1 receptor family member, in cardiomyocytes and myocardial infarction. Circulation 2002, 106(23):2961-6.

3. Rehman SU, Mueller T, Januzzi JL Jr: Characteristics of the novel interleukin family biomarker ST2 in patients with acute heart failure. J Am Coll Cardiol 2008, 52(18):1458-65.

4. Pascual-Figal DA, Ordonez-Lianos J, Tornel PL, Vazquez R, Puig T, Valdes M, Cinca J, de Luna AB, Bayes-Genis A, MUSIC Investigators: Soluble ST2 for predicting sudden cardiac death in patients with chronic heart failure and left ventricular systolic dysfunction. J Am Coll Cardiol 2009, 54(23):2174-9.

5. Shimpo M, Morrow DA, Weinberg EO, Sabatine MS, Murphy SA, Antman EM, Lee RT: Serum levels of the interleukin-1 receptor family member ST2 predict mortality and clinical outcome in acute myocardial infarction. Circulation 2004, 109(18):2186-90

6. Weir RA, Miller AM, Murphy GE, Clements S, Steedman T, Connell JM, Mclnnes IB, Dargie HJ, McMurray JJ: Serum soluble ST2: a potential novel mediator in left ventricular and infarct remodeling after acute myocardial infarction. J Am Coll Cardiol 2010, 55(3):243-50.

7. Sabatine MS, Morrow DA, Higgins LJ, MacGillivray C, Guo W, Bode C, Rifai N, Cannon CP, Gerszten RE, Lee RT: Complementary roles for biomarkers of biomechanical strain ST2 and N-terminal prohormone B-type natriuretic peptide in patients with ST-elevation myocardial infarction. Circulation 2008, 117(15):1936-44.

8. Januzzi JL Jr, Peacock WF, Maisel AS, Chae CU, Jesse RL, Baggish AL, O'Donoghue M, Sakhuja R, Chen AA, van Kimmenade RR, Lewandrowski KB, Lloyd-Jones DM, Wu AH: Measurement of the interleukin family member ST2 in patients with acute dyspnea: results from the PRIDE (Pro-Brain Natriuretic Peptide Investigation of Dyspnea in the Emergency Department Study) study. J Am Coll Cardiol 2007, 50(7):607-13.

9. Januzzi JL Jr, Rehman S, Mueller T, van Kimmenade RR, Lloyd-Jones DM: Importance of biomarkers for long term mortality prediction in acutely dyspneic patients. Clin Chem 2010, 56(12):1814-21.

10. Dieplinger B, Gegenhuber A, Kaar G, Poelz W, Haltmayer M, Mueller T: Prognostic value of established and novel biomarkers in patients with shortness of breath attending an emergency department. Clin Biochem 2010, 43(9):714-9.

11. Shah RV, Chen-Tournoux AA, Picard MH, van Kimmenade RR, Januzzi JL: Serum levels of the interleukin-1 receptor family member ST2, cardiac 
structure and function and long term mortality in patients with acute dyspnea. Circ Heart Fail 2009, 2(4):311-9.

12. Haraldsen G, Balogh J, Pollheimer J, Sponheim J, Kuchler AM: Inteleukin-33cytokine of dual function or novel alarmin? Trends Immunol 2009, 30:227-233.

13. Miller AM: Role of IL-33 in inflammation and disease. Journal of Inflammation 2011, 8:22-34.

14. McLaren JE, Michael DR, Salter RC, Ashlin TG, Calder CJ, Miller AM, Liew FY, Ramji DP: IL-33 reduces macrophage foam cell formation. J Immunology 2010, 185:1222-1229.

15. Miller AM, Xu D, Asquith DL, Denby L, Li Y, Satar N, Baker AH, Mclnnes IB, Liew FY: IL-33 reduces the development of atherosclerosis. J Exp Med 2008, 205:339-346.

16. Sanada S, Hakuno D, Higgins LJ, Schreiter ER, McKenzie AN, Lee RT: IL-33 and ST2 comprise a critical biomechanically induced and cardioprotective signaling system. J Clin Invest 2007, 117(6):1538-49.

17. Seki K, Sanada S, Kudinova AY, Steinhauser MI, Handa V, Gannon J, Lee RT: Inteleukin-33 prevents apoptosis and improves survival after experimental myocardial infarction through ST2 signaling. Circ Heart Fail 2009, 2:684-691.

18. Schmitz J, Owyang A, Oldhman E, Song Y, Murphy E, McClanahan TK, Zurawski E, Moshrefi M, Qin J, Li X, Gorman DM, Bazan JF, Kastelein RA: IL33, an interleukin-1-like Cytokine that Signals via the IL-1 ReceptorRelated Protein ST2 and Induces T Helper Type 2-Associated Cytokines. Immunity 2005, 23:479-490.

19. Moulin D, Donze O, Tabalot-Ayer D, Mezin F, Palmer G, Gabay C: Interleukin (IL)-33 induces the release of proinflammatory mediators by mast cells. Cytokine 2007, 40:216-225.

20. Brett Chery W, Yoon J, Bartemes KR, Lijima K, Kita H: A novel IL-1 family cytokine, IL-33, potently activates human eosinophils. Journal of Allergy and Clinical Immunology 2008, 121:1484-1490.

21. Miller AM, Asquith DL, Hueber AJ, Anderson LA, Holmes WM, McKenzie AN, Xu D, Sattar N, McInnes IB, Liew FY: Interleukin-33 induces protective effects in adipose tissue inflammation during obesity in mice. Circ Res 2010, 185:1222-1229.

22. Badawi A, Klip A, Haddad P, Cole D, Bailo BG, Karmali M: Type 2 diabetes mellitus and inflammation: Prospects for biomarkers of risk and nutritional intervention. Diabetes, Metabolic Syndrome and Obesity: Targets and Therapy 2010, 3:173-186.

23. Dehghan A, Kardys I, De Maat MP: Genetic variation, C-reactive protein levels and incidence of diabetes. Diabetes 2007, 56:872-878.

24. Lee CC, Adler Al, Sandhu MS: Association of C-reactive protein with type 2 diabetes: prospective analysis and meta-analysis. Diabetologia 2009, 52:1040-1047.

25. Cosson S, Kevorkian JP: Left ventricular diastolic dysfunction: an early sign of diabetic cardiomyopathy? Diabetes Metab 2003, 29(5):455-66.

26. Kiencke $S$, Handschin R, von Dahlen R, Muser J, Brunner-Larocca HP, Schumann J, Felix B, Berneis K, Rickenbacher P: Pre-clinical diabetic cardiomyopathy: prevalence, screening, and outcome. Eur I Heart Fail 2010, 12(9):951-7.

27. Vignon-Zellweger N, Relle K, Kienten E, Seider P, Sharkovska J, Heiden S, Kalk P, Schwab K, Albrecht-Kupper B, Theuring F, Stasch JP, Hocher B: Endothelin-1 overexpression restores diastolic function in Enos knockout mice. J Hypertens 2011, 29:961-970.

28. Yndestad A, Marshall AK, Hodgkinson JD, Thamel L, Sugden PH: Clerk A: modulation of interleukin signalling and gene expression in cardiac myocytes by enothelin-1. Int J Biochem Cell Biol 2010, 42:263-272.

29. Beutler BA: TLRs and innate immunity. Blood 2009, 113:1399-1407.

30. Liu J, Buckley JM, Redmond PH, Wang JH: ST2 Negatively Regulates TLR2 Signaling, but Is Not Required for Bacterial Lipoprotein-Induced Tolerance. The Journal of Immunology 2010, 184:5802-5808.

31. Sweet MJ, Leung BP, Kang D, Sogaard M, Schulz K, Trajkovic C, Campbell C, $\mathrm{Xu} D$, Liew FY: A novel pathway regulating lipopolysaccharide-induced shock by ST2/T1 via inhibition of Toll-like receptor 4 expression. J Immunology 2001, 166:6633-6639.

32. Takenazo NM, Hayakawa H, Hayakawa S, Aoki S, Yanagisawa H, Endo S, Tominaga S: ST2 suppresses IL-6 production via the inhibition of IkappaB degradation induced by LPS signal in THP-1 cells. Biochem Biophys Res Commun 2006, 341:425-432.
33. Humphreys NE, Xu D, Hepworth MR, Liew FY, Grencis RK: IL-33 a potent inducer of adaptive immunity to intestinal nematobes. J Immunol 2008, 180:2443-2449.

34. Zdravkovic N, Shahin A, Arsenijevic N, Lukic ML: Regulatory T cells and ST2 signaling control diabetes induction with multiple low doses of streptozotocin. Molecular Immunology 2009, 47:28-36.

35. Li j, Jin C, Cleveland JC, Ao L, Xu D, Fullerton DA, Meng X: Enhanced inflammatory responses to toll-like receptor $2 / 4$ stimulation in type 1 diabetic coronary artery endothelial cells: the effect of insulin. Cardiovasc Diabetol 2010, 9:90.

36. Foryst-Ludwig A, Hartge M, Clemenz M, Sprang C, Heb K, Marx N: PPARgamma activation attenuates T-lymphocyte-dependent inflammation of adipose tissue and development of insulin resistance in obese mice. Cardiovasc Diabetol 2010, 9:64.

doi:10.1186/1475-2840-10-101

Cite this article as: Fousteris et al:: Toll/Interleukin-1 receptor member ST2 exhibits higher soluble levels in type 2 diabetes, especially when accompanied with left ventricular diastolic dysfunction. Cardiovascular Diabetology 2011 10:101.

\section{Submit your next manuscript to BioMed Central and take full advantage of:}

- Convenient online submission

- Thorough peer review

- No space constraints or color figure charges

- Immediate publication on acceptance

- Inclusion in PubMed, CAS, Scopus and Google Scholar

- Research which is freely available for redistribution

Submit your manuscript at www.biomedcentral.com/submit
Biomed Central 